\title{
Youth and Age
}

He had failed in everything earthly, but he had finished his great poem "to which heaven and earth had put their hand," and which has lifted him for ever among the immortals.

J. F. Makepeace.

\section{YOUTH AND AGE}

\ $\mathrm{HEN}$ we are old, and these our blithesome days Are like a dream to one from slumber torn,

Who in the austere twilight of the morn

Tries vainly to recall the sunlit ways

That but a moment since beguiled his gaze,-

$\mathrm{Ah}$, let us, in the land of eld forlorn,

Where old griefs dwell and sorrows newly-born,

Deny no suppliant in youth's name who prays.

Let us look backward from Death's shadowing wings,

Nor scorn the dreamer's trancèd melody

Because we have forgot the tongue he sings;

But rather deem that Youth may prove to be

The final goal of all Time's wanderings,

And Age a false and fleeting phantasy.

Sister M. Benvenuta, O.P. 